\title{
Utilization of slaughter plant waste proteins in gypsum retarder: A case study
}

\author{
Chen Xiong-mu ${ }^{1}$, Zhang Meng-meng ${ }^{1}$, Li Ling-xiao ${ }^{2}$ and Zhao Feng-qing ${ }^{1,2}$ \\ ${ }^{1}$ Department of Chemical Engineering, Hebei University of Science \& Technology, Shijiazhuang, 050018, China \\ ${ }^{2}$ Hebei Engineering Research Center of Solid Waste Utilization, Shijiazhuang, 050000, China
}

\begin{abstract}
Slaughter plant waste proteins contain animal hair, bones, nails etc. Improper treatment will pollute the environment and result in waste of resources. A process is proposed to prepare gypsum retarder from such waste, firstly through hydrolysis at acidic condition, and then neutralized with alkalis. The optimal conditions for acid hydrolysis are obtained: concentration of HCL $4.8 \mathrm{~mol} / \mathrm{L}$, reaction temperature $98{ }^{\circ} \mathrm{C}$, reaction time $7 \mathrm{~h}$. After neutralization (to $\mathrm{pH}=7$ ), the product can be used as gypsum retarder (retarder $\mathrm{A}$ ). Compared with commonly used retarder, citric acid, the mechanical strength loss of gypsum paste containing retarder A is much lower. It is a costeffective approach for safe utilization of slaughter plant waste proteins.
\end{abstract}

\section{Introduction}

Slaughter plant waste proteins include animal hair, bone and nail, which contain a lot of proteins. Most of these by-products of meat industry are not directly edible and have less appeal in fresh and frozen market. At present, it is mainly used for producing animal feed or feed additives, pesticides, fertilizers and pharmaceuticals. But there is a drawback for these: the toxic substances could be transmitted along the food chain, and would be a potential threat to human health.

Considering that these wastes contain plenty of proteins, they can be used to produce gypsum retarder, which not only reduce the risk to the health of human and animals, but also have economic benefit $[1,2]$. Much work has been done in this field these years and the hydrolysis of proteins is often the key to prepare gypsum retarder [3-5]. The final hydrolysis products are mostly amino acids. The current methods of preparing amino acids by hydrolysis of protein include acid hydrolysis [6], alkali hydrolysis [7], enzymatic hydrolysis, high temperature hydrolysis and high pressure hydrolysis. They all have their own advantages and disadvantages. However, using slaughter plant waste proteins as material to prepare gypsum retarder has not yet been reported.

The present study was undertaken to treat slaughter plant waste proteins firstly by acid hydrolysis, then alkali neutralized to produce a gypsum retarder, investigating the effect on setting time.

\section{Experimental}

\subsection{Materials}

Slaughter plant waste proteins were bought on market; concentrated hydrochloric acid, formic acid and caustic soda are analytical reagents. The FGD gypsum used in this work was provided by Shijiazhuang Xibaipo Power Plant with the composition: $\mathrm{SO}_{3}-49.27 \%, \mathrm{CaO}-33.42 \%$, $\mathrm{SiO}_{2}-0.42 \%, \mathrm{MgO}-1.08 \%, \mathrm{Fe}_{2} \mathrm{O}_{3}-0.32 \%, \mathrm{Al}_{2} \mathrm{O}_{3}-0.82 \%$. The properties of the calcined hemihydrate gypsum ( Prepared by heating the FGD gypsum at $160-180{ }^{\circ} \mathrm{C}$ for $1.5 \mathrm{hr}$.) are shown in Table 1.

Table 1 Physical and mechanical properties of gypsum

\begin{tabular}{|c|c|c|c|c|}
\hline \multicolumn{2}{|c|}{ Setting tine [min] } & \multirow[b]{2}{*}{$\begin{array}{c}\text { Bending } \\
\text { strength } \\
{[\mathrm{MPa}]}\end{array}$} & \multirow[b]{2}{*}{$\begin{array}{c}\text { Compressive } \\
\text { strength } \\
{[\mathrm{MPa}]}\end{array}$} & \multirow[b]{2}{*}{$\begin{array}{c}\text { Standard } \\
\text { consistency }\end{array}$} \\
\hline $\begin{array}{c}\text { Initial } \\
\text { setting } \\
\text { time }\end{array}$ & $\begin{array}{c}\text { Final } \\
\text { setting } \\
\text { time }\end{array}$ & & & \\
\hline 9 & 12 & 6.3 & 20.6 & 0.57 \\
\hline
\end{tabular}

\subsection{Methods}

Slaughter plant waste protein is first treated to remove impurities, then mixed with acid solution according to the desired proportion, through hydrolysis, to obtain compound amino acid solution. Add alkali and adjust $\mathrm{pH}=7$, to obtain final product, gypsum retarder A. See Figure 1..

Six prismatic $40 \times 40 \times 160 \mathrm{~mm}$ specimens were made from each formulation. The normal consistency and setting time of hemihydrate gypsum were determined as per GB/T17669.3-1999. The specimens were cast at normal consistency, cured for 3 days, then dried at $60{ }^{\circ} \mathrm{C}$ 
to constant mass, and tested for compressive and flexural strength values.

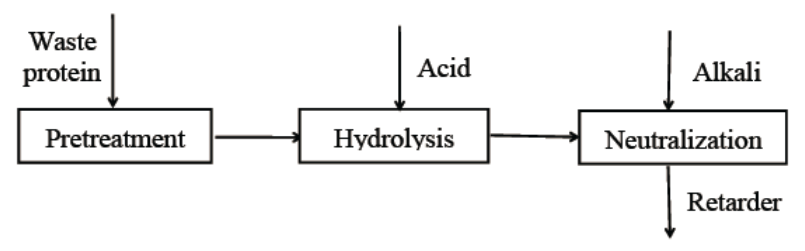

Figure 1. Process of gypsum retarder from waste protein

\section{Results and discussion}

\subsection{Selection of acid for hydration}

Based investigative experiment, hydrochloric acid, mixture of hydrochloric acid and folic acid were selected for hydration of Slaughter plant waste proteins, with various dilution ratio, time and temperature. See Figure 2.

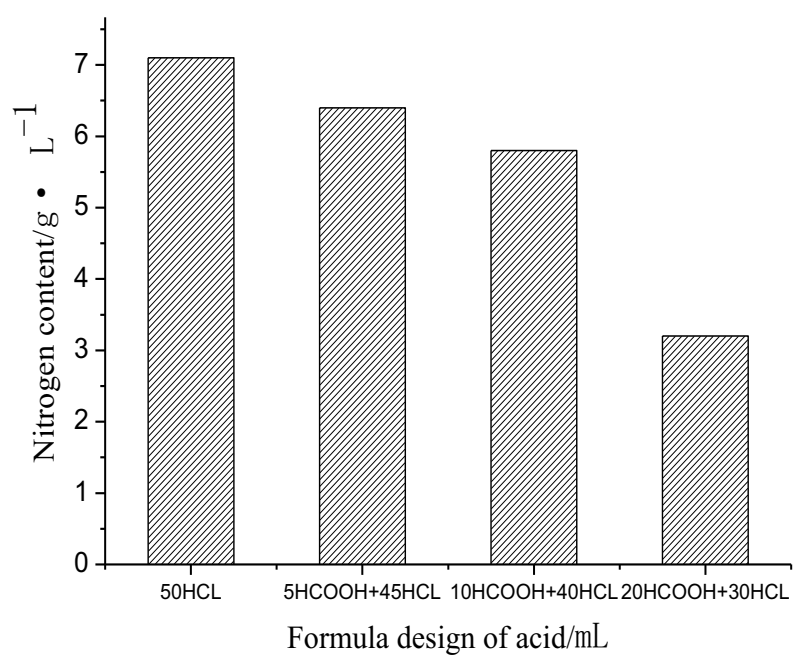

Figure 2. Amino acid nitrogen content of different cases

The results show that the content of formic acid in mixed acid has negative effect on amino acid nitrogen content in hydration product. Pure hydrochloric acid behaves best with the amino acid nitrogen content of 7.1 $\mathrm{g} / \mathrm{L}$.

\subsection{Concentration of HCL}

Initial experiments proved that the concentration of acid has obvious effect on the dissolving rate of waste proteins. It is necessary to find the optimal concentration of hydrochloric acid. Thus the effects of the concentration of hydrochloric acid on the maximum dissolved raw materials and the corresponding amino acid nitrogen content were investigated under the condition of reaction temperature $95{ }^{\circ} \mathrm{C}$ and reaction time $4 \mathrm{~h}$. See Figure 3.

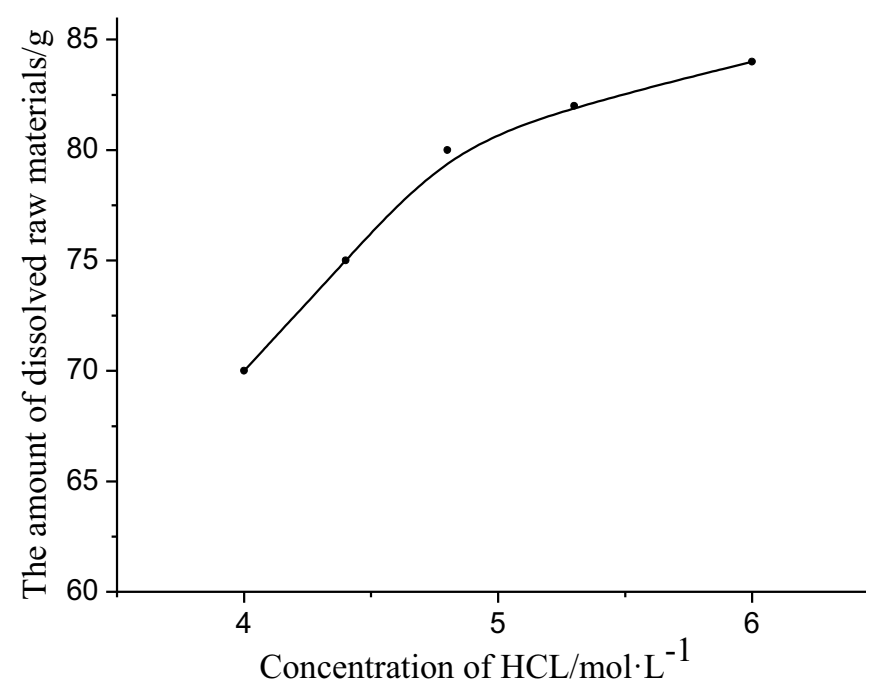

(a)

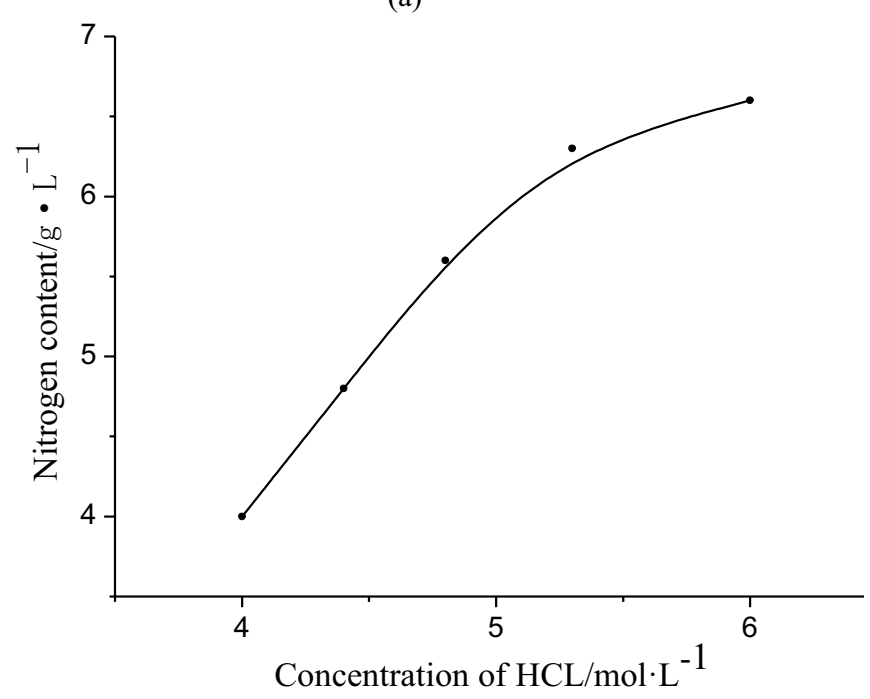

(b)

Figure 3. Effect of concentration of HCL on dissolved amount of raw material l(a) and nitrogen content (b)

It can be known from Figure 3(a) that the amount of dissolved raw material rapidly increases with the increase of the concentration of HCL. When the concentration of hydrochloric acid increases, the amount of the dissolved raw materials increases steadily. Figure 3(b) shows that with the increase of HCL concentration, the content of amino nitrogen also increases. Higher concentration of HCL will consume much more alkali in the later neutralization process. Therefore, the proper concentration of $\mathrm{HCL}$ is $4.8 \mathrm{~mol} / \mathrm{L}$.

\subsection{Reaction temperature}

With the concentration of HCL $4.8 \mathrm{~mol} / \mathrm{L}$ and reaction time of $4 \mathrm{~h}$, reaction temperature as control factor, the amount of dissolved raw material and the amino acid nitrogen content were measured.

It can be known from Figure 4(a) that the amount of dissolved raw material is increased with the increase of temperature. With the increase of the reaction 
temperature, the molecular activity was improved, which promote the catalytic activity of HCL. When reaction temperature is above $98{ }^{\circ} \mathrm{C}$, the amount of dissolved raw material tends to be gentle. Figure 4(b) shows that with the increase of temperature, the content of amino nitrogen increases. When the temperature is above $98{ }^{\circ} \mathrm{C}$, part of the amino acid decompose, accompanied by unpleasant odours. Therefore, the optimal acid hydrolysis temperature is $98{ }^{\circ} \mathrm{C}$.

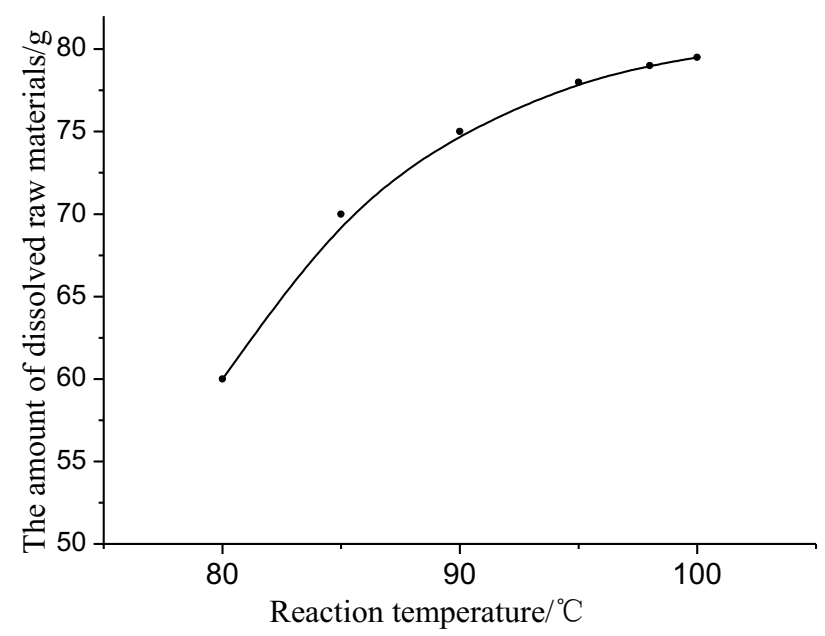

(a)

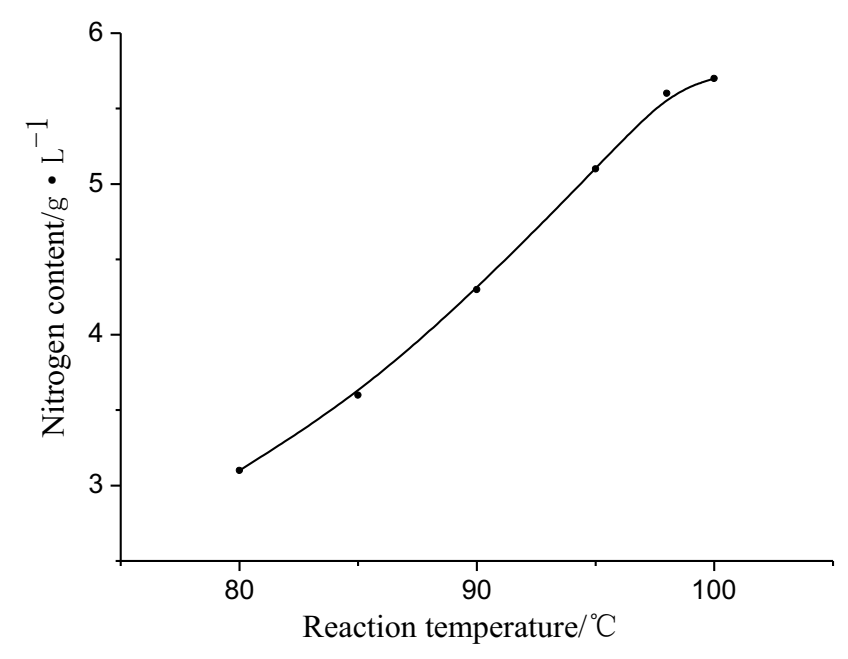

(b)

Figure 4. Effect of temperature on the dissolved amount of raw material (a) and nitrogen content (b)

\subsection{Hydrolysis time}

With mass ratio of slaughter plant waste protein and HCL solution $1: 2$, concentration of $\mathrm{HCL} 4.8 \mathrm{~mol} / \mathrm{L}$, reaction temperature $98^{\circ} \mathrm{C}$, the amino acid type nitrogen content was measured. The results are shown in Figure 5.

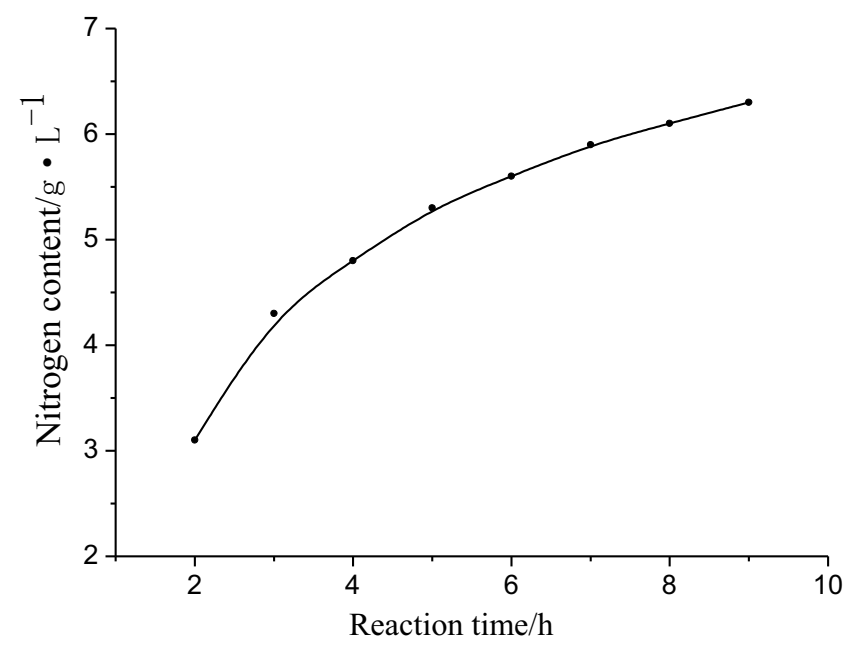

Figure 5. Content of amino nitrogen vs. reacton time

The result show that the content of amino acid type nitrogen gradually increases with the increase in reaction time. Considering that longer hydrolysis time will result in loss in efficiency and increase in cost. The suitable reaction time is $7 \mathrm{~h}$.

In summary, the optimal conditions for acid hydrolysis of slaughter plant waste protein were obtained: HCL concentration $4.8 \mathrm{~mol} / \mathrm{L}$, reaction time $7 \mathrm{~h}$, and the reaction temperature $98^{\circ} \mathrm{C}$.

\subsection{Application in gypsum paste}

The compound amino acid solution was mixed with caustic soda, adjusting $\mathrm{pH}$ to 7 , to obtain gypsum retarder A. The set-retarding performance of retarder A was investigated. The results are shown in Figure 6. We can see that retarder A has significant retarding effect for gypsum paste. When the dosage is $1.25 \%$, the initial and final setting time was $78 \mathrm{~min}$. and $121 \mathrm{~min}$. respectively, which can meet the ordinary uses as gypsum retarder. If needed, the final retarding time of gypsum paste can be longer than $180 \mathrm{~min}$. with the dosage above $1.5 \%$.

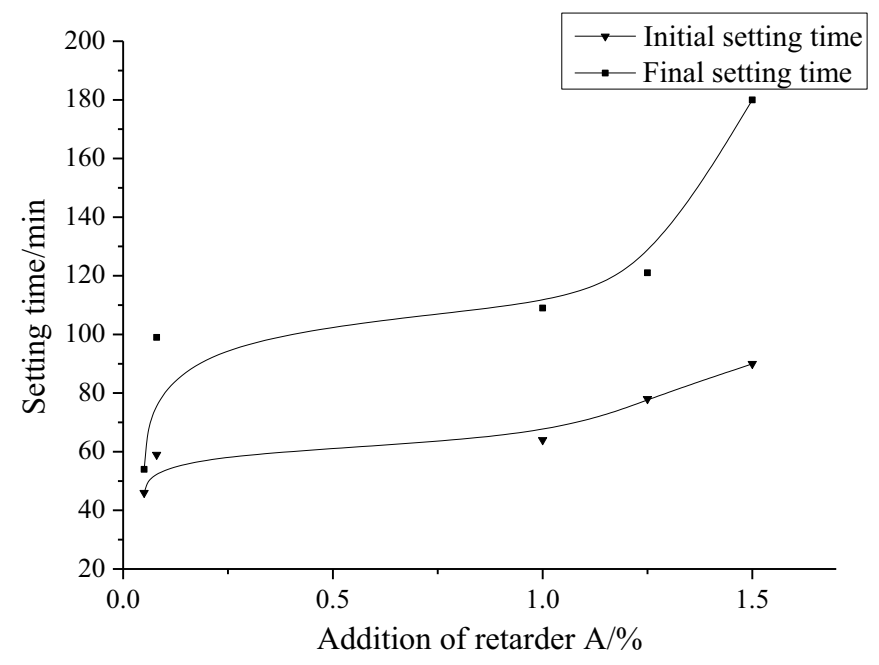

Figure 6. Effect of retarder A on setting time of FGD gypsum 
With the roughly same controlled initial setting time of 80 min., the mechanical strength loss values of gypsum paste using retarder A and citric acid were measured. The results are shown in Table 2.

Table 2 Effect of different retarder on mechanical strength

\begin{tabular}{ccc}
\hline \multirow{2}{*}{ Retarder } & \multicolumn{2}{c}{$\begin{array}{c}\text { Mechanical strength of gypsum paste } \\
\text { gypsum paste (MPa) }\end{array}$} \\
\cline { 2 - 3 } & Bending strength & Compressive strength \\
\hline 0 & 6.3 & 20.6 \\
Retarder A & 3.3 & 9.7 \\
Citric acid & 2.7 & 7.5 \\
\hline
\end{tabular}

The results show that all the set retarders have negative effect on the mechanical strength of gypsum paste, while prolonging the setting time. However, different retarder behaves different. It is clear that the mechanical strength loss of the gypsum paste containing citric acid is much higher than that of gypsum paste containing retarder $\mathrm{A}$.

\section{Retarding mechanism}

The hydration process of hemi-gypsum in paste is mainly composed of three steps:

- Solving of gypsum in water, producing $\mathrm{Ca}^{2+}, \mathrm{SO}_{4}{ }^{2-}$

- Formation of dihydrate gypsum crystal nucleus

Growth of gypsum crystal and formation of binding.

As for the retarding mechanism, it may attribute to the complexation of active groups in retarder A with calcium in the paste. Compound amino acid is adsorbed on the surface of the gypsum particle by this complexation, forming protective colloid layer on the gypsum crystal nucleus, wrapped up the particle. Thus the growth of gypsum crystal was inhibited to some extent, delaying the setting time of gypsum paste. See Figure 7 [1].

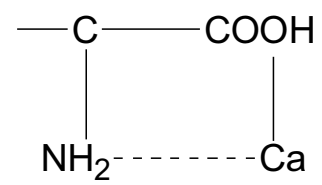

Figure 7. Complexation of retarder $\mathrm{A}$ with $\mathrm{Ca}^{2+}$

\section{Summary}

Slaughter plant waste proteins (animal hair, bone and nail etc.) can be used to prepare gypsum retarder by acid hydrolysis and then treated with caustic soda. It is a safe approach for utilization of slaughter plant waste protein.

The proper conditions for acid hydrolysis were: concentration of HCL $4.8 \mathrm{~mol} / \mathrm{L}$, reaction temperature of $98{ }^{\circ} \mathrm{C}$, reaction time $7 \mathrm{~h}$. The compound amino acid was then neutralized (to $\mathrm{pH}=7$ ) with caustic soda, to obtain gypsum retarder A. When it is used as gypsum retarder, the proper dosage is $1.5 \%$ in the mixture. It also shows that, when needed, the final retarding time of gypsum paste can be longer than $180 \mathrm{~min}$. with the dosage above $1.5 \%$.

Compared with commonly used retarder citric acid, the mechanical strength loss of gypsum paste containing retarder $\mathrm{A}$ is much lower. The mechanical loss of different cases is probably because of different effects on the gypsum crystal growth.

\section{References}

1. F.Q. Zhao, X.Q Ren, Q.Q. Hu, Study on Preparation of desulfurization gypsum retarder by penicillin waste mycelium, Environmental science and technology. 2, 134-137 (2014)

2. H.J. Yang, Y. Mu, X.Q. Ren, et al, Study on Preparation of building gypsum retarder by waste mycelium, Journal of Hebei University of Science and Technology. 34, 10-15 (2013)

3. J. Liang, Z Li, X.Yan, et al, Study on Gypsum Plasters with Modified Waste Mycelium as Retarder, Proceedings of International Symposium on Computers and Informatics. 13, 2251-2258 (2015)

4. M.M. Chen, M.M. Zhang, F.Q. Zhao, Preparation of Gypsum Retarding Material and Activated Carbon from Waste Mycelium, Key Engineering Materials. 703, 297-300 (2016)

5. M.M. Zhang, M.M. Chen, et al, Improving Water proof Property of Gypsum Block with OrganicInorganic Compound Materials, Proceedings of 2nd International Conference on Material Engineering and Application, 707-711 (2015)

6. G.F. Ren, Progress in production and application of amino acid, J. Journal of amino acids. 3 (1987) 19-28.

7. Y.C. Wang, Study on hydrolysis of keratin, J. Chemical World. 9, 422-423 (1988) 